\title{
Pengaruh Return on Equity, Earning per Share (EPS), dan Debt to Equity Ratio terhadap Price Earning Ratio (PER) Pada PT Indofood Sukses Makmur. Tbk Periode 2012-2014
}

\author{
Mulyani, L. ${ }^{1}$., Pitaloka, E. ${ }^{2}$ \\ ${ }^{1}$ Program Studi Manajemen, Universitas Pembangunan Jaya, 1ydia.mulyani@gmail.com \\ ${ }^{2}$ Program Studi Manajemen, Universitas Pembangunan Jaya, oka@ upj.ac.id
}

\begin{abstract}
The purpose of this study is to analyze the effect of effect Return On Equity, Earnings Per Share, and Financial Leverage on Price Earning Ratio at PT. Indofood Sukses Makmur. Tbk period 2012-2014. In this study Price Earning Ratio is the dependent variable. Return on Equity, Earnings per Share, and Debt to Equity Ratio are independent variables. The data were analyzed by multiple regression. The result showed that partially both Return on Equity and Debt to Equity Ratio have a significant influence on Price Earning Ratio. Earning per share is insignificant on Price Earning Ratio. Return on Equity, Earnings per Share, and Debt to Equity Ratio simultaneously significant on Price Earning Ratio.
\end{abstract}

Keywords : Return on Equity (ROE), Earning per Share (EPS), Debt to Equity Ratio (DER), Price Earning Ratio (PER)

Abstrak : Penelitian ini bertujuan mengetahui pengaruh Return on Equity, Earning
per Share, dan Debt to Equity Ratio (DER) terhadap Price Earning Ratio pada PT.
Indofood Sukses Makmur Tbk periode 2012-2014. Price Earning Ratio sebagai
variabel terikat dan Return on Equity, Earning per Share, dan Debt to Equity Ratio
sebagai variabel bebas. Teknik analisis data yang digunakan adalah regresi
berganda. Hasil penelitian ini menunjukkan secara parsial variabel Return on Equity
dan Debt to Equity Ratio (DER) mempengaruhi Price Earning Ratio secara
signifikan, sedangkan variabel Earning per Share tidak berpengaruh terhadap
Price Earning Ratio. Namun hasil pengujian secara simultan menunjukkan bahwa
semua variabel bebas berpengaruh terhadap Price Earning Ratio.
Kata kunci : Return on Equity (ROE), Earning per Share (EPS), Debt to Equity
Ratio (DER), Price Earning Ratio (PER)

\section{LATAR BELAKANG}

Bursa Efek Indonesia merupakan tempat atau wadah bagi para pelaku saham untuk memperdagangkan atau memperjualbelikan setiap saham efek yang mereka miliki dan ingin mereka beli. Menurut UUPM nomor 8 tahun 1995, Perusahaan Efek adalah pihak yang melakukan kegiatan usaha sebagai penjamin emisi efek, perantara pedagang efek dan/atau manajer investasi. Pihak yang dimaksud adalah perusahaan yang berbadan hukum Perseroan Terbatas (PT). Untuk mempermudah pemetaan perusahaan yang terdaftar di Bursa Efek Indonesia, maka di bentuk perbedaan menjadi 9 sektor yaitu sektor Pertanian, Pertambangan, Industri Dasar dan Kimia, Aneka Industri, Barang Konsumsi, Properti Real Estate dan Konstruksi Bangunan, Infrastruktur dan Transportasi, Keuangan, Perdagangan Jasa dan Investasi. Diantara sektor tersebut, yang dijadikan objek penelitian yaitu Sektor Barang Konsumsi, Sub Sektor Makanan dan Minuman.

Semua perusahaan pada 9 sektor tersebut memiliki hal-hal tertentu yang menarik bagi investor sehingga mau membeli saham suatu perusahaan. Umumnya dalam membeli saham investor akan melakukan analisis saham. Salah satu analisis yang digunakan oleh investor 
adalah analisis fundamental. analisis Fundamental dibutuhkan untuk mengestimasi pergerakan saham (Fahmi, 2013). Beberapa pendekatan yang dapat digunakan untuk mengestimasi harga saham adalah Relative Approach, Discounted Approach, dan Factor Model. Relative Approach meliputi Price Earning Ratio, Price Book Value Ratio dan Price Devidend Ratio.

Pendekatan Price Earning Ratio dalam Relative Approach merupakan pendekatan yang sangat terkenal dan sudah banyak dipakai di berbagai negara untuk mengestimasi saham karena kepopulerannya (Samsul, 2011). Begitupun di Indonesia, pendekatan atau indikator ini juga sering digunakan oleh para investor untuk dijadikan indikator untuk melihat apakah harga tersebut mahal, murah atau wajar. Jika Price Earning Ratio lebih tinggi dari dibandingkan dengan pesaingnya, maka perlu berpikir dua kali untuk membeli saham tersebut. Price Earning Ratio adalah salah satu ukuran paling dasar dalam analisis saham fundamental (Fahmi, 2013).

$$
\text { Price Earning Ratio adalah }
$$
perbandingan antara harga saham dengan laba bersih perusahaan, dimana harga saham sebuah emiten dibandingkan dengan laba bersih yang dihasilkan oleh emiten tersebut dalam setahun. Karena yang menjadi fokusnya adalah laba bersih yang dihasilkan perusahaan, maka dengan mengetahui Price Earning Ratio sebuah emiten, bisa diketahui apakah harga sebuah saham tergolong wajar atau tidak. Oleh karena itu, Price Earning Ratio ini sangat menarik perhatian para Investor dalam pendekatan untuk mengestimasi saham, maka menentukan faktor-faktor apakah yang mempengaruhi Price Earning Ratio dengan mengetahui seberapa jauh faktorfaktor tersebut mempengaruhi Price Earning Ratio adalah sangat penting.

Salah satu faktor yang mempengaruhi Price Earning Ratio adalah Return On Equity (ROE). Menurut Purwaningrum (2011) Hubungan Return on Equity terhadap Price Earning Ratio adalah positif. ROE merupakan kemampuan modal sendiri untuk menghasilkan profit bagi pemegang saham. Menurut Hayati (2010) Return on Equitydigunakan untuk mengukur tingkat keuntungan dari investasi pemilik modal dan dihitung berdasarkan pembagian antara laba bersih dengan modal sendiri.

Faktor lain yang juga mempengaruhi Price Earning Ratio adalah Earning per Share. Menurut Sitepu dan Efendi (2014) Earning Per Share menunjukkan ukuran kinerja perusahaan dalam menghasilkan laba (earnings) yang merupakan return bagi investor akan penanaman modal investasinya. Earning per Share adalah rasio yang menunjukkan berapa besar keuntungan (return) yang diperoleh investor atau pemegang saham per saham. Studi terdahulu juga menunjukan bahwa Faktor juga mempengaruhi Price Earning Ratio.

Financial Leverage adalah penggunaan hutang sebagai sumber pembiayaan perusahaan. Financial Leverage yang biasa digunakan aalah Debt to Equity Ratio (DER) (Sunaryo, 2011). Penelitian Sunaryo (2011) menunjukan bahwa (DER) berpengaruh terhadap Price Earning Ratio. Hubungannya dengan Price Earning Ratio adalah negatif.

Dari 9 sektor industri yang ada, sektor makanan dan minuman memberikan kontribusi cukup besar sekitar 14\% terhadap PDB (BPS, 2015). Hal ini menjadikan perusahaan di sektor industri makanan dan minuman menarik untuk diteliti. Di BEI terdapat 15 perusahaan sektor makanan dan minuman yang terdaftar. Berdasarkan profirnya, profil 15 perusahaan tersebut tersaji dalam Tabel 1.

Dari tabel tersebut PT. Indofood Sukses Makmur. Tbk (INDF) memiliki profit terbesar. Hal ini menjadi salah satu alasan investor untuk memiliki saham INDF. Namun data laporan keuangan INDF menunjukan ada beberpa hal yang tidak konsisten dalam pergerakan antara ROE, EPS dan DER dengan PER seperti yang tersaji dalam Tabel 2, Tabel 3 dan Tabel 4. 
Tabel 1. Kinerja Perusahaan Pendekatan Profit Periode 2014

\begin{tabular}{|c|l|r} 
No & \multicolumn{1}{|c}{ Kode dan Nama Perusahaan } & Tahun 2014 \\
\hline $\mathbf{1 .}$ & INDF (Indofood Sukses Makmur Tbk) & $5,146,323$ \\
\hline $\mathbf{2 .}$ & ICBP (Indofood CBP Sukses Makmur Tbk) & $2,531,681$ \\
\hline $\mathbf{3 .}$ & MLBI (Multi Bintang Indonesia) & 794,883 \\
\hline $\mathbf{4 .}$ & MYOR (Mayora Indah Tbk) & 409,825 \\
\hline $\mathbf{5 .}$ & AISA (Tiga Pilar Sejahtera Food Tbk) & 378,142 \\
\hline $\mathbf{6 .}$ & DLTA (Delta Djakarta Tbk) & 288,073 \\
\hline $\mathbf{7 .}$ & ROTI (Nippon Indosari Corpindo) & 188,578 \\
\hline $\mathbf{8 .}$ & ULTJ (Ultrajaya Milk Industry \& Trading Co, Tbk) & 130,313 \\
\hline $\mathbf{9 .}$ & STTP (Siantar Top Tbk) & 123,465 \\
\hline $\mathbf{1 0 .}$ & CEKA (Cahaya Kalbar Tbk) & 41,001 \\
\hline $\mathbf{1 1}$ & ADES (Akasha Wira International Tbk) & 31,021 \\
\hline $\mathbf{1 2 .}$ & SKLT (Sekar Laut Tbk) & 16,481 \\
\hline $\mathbf{1 3 .}$ & ALTO (Tri Banyan Tirta Tbk) & $(10,135)$ \\
\hline $\mathbf{1 4}$. & PSDN (Prasidha Aneka Niaga Tbk) & $(28,175)$ \\
\hline $\mathbf{1 5 .}$ & SKBM (Sekar Bumi Tbk) & - \\
\hline
\end{tabular}

Sumber: Diolah dari Publikasi Bursa Efek Indonesia 2015

Tabel 2. Hubungan antara ROE dan PER pada PT. Indofood Sukses Makmur

\begin{tabular}{|c|c|c|c|c|c|}
\hline Bulan & ROE & Arah & PER & Arah & Keterangan \\
\hline Jan-12 & 16.7 & & 8.3 & & \\
\hline Feb-12 & 16.7 & tetap & 8.82 & naik & tidak konsisten \\
\hline Mar-12 & 15.9 & turun & 8.49 & turun & konsisten \\
\hline Apr-12 & 15.9 & tetap & 8.49 & tetap & konsisten \\
\hline Mei-12 & 15.9 & tetap & 7.93 & turun & tidak konsisten \\
\hline Jun-12 & 15.9 & tetap & 8.14 & naik & tidak konsisten \\
\hline Jul-12 & 15.9 & tetap & 9.06 & naik & tidak konsisten \\
\hline Agt-12 & 15.8 & turun & 9.33 & naik & tidak konsisten \\
\hline Sep-12 & 15.8 & tetap & 9.77 & naik & tidak konsisten \\
\hline Okt-12 & 15.8 & tetap & 9.85 & naik & tidak konsisten \\
\hline Nov-12 & 15.4 & turun & 10.02 & naik & tidak konsisten \\
\hline Des-12 & 15.4 & tetap & 10.02 & tetap & konsisten \\
\hline
\end{tabular}

Sumber: Diolah dari publikasi Bursa Efek Indonesia 2015

Tabel 3. Hubungan antara EPS dan PER pada PT. Indofood Sukses Makmur

\begin{tabular}{|c|c|c|c|c|c|}
\hline Bulan & EPS & Arah & \multicolumn{1}{c}{ PER } & Arah & Keterangan \\
\hline Jan-12 & 578 & & 8.3 & & \\
\hline Feb-12 & 578 & tetap & 8.82 & naik & tidak konsisten \\
\hline Mar-12 & 571 & turun & 8.49 & turun & konsisten \\
\hline Apr-12 & 571 & tetap & 8.49 & tetap & konsisten \\
\hline Mei-12 & 596 & naik & 7.93 & turun & tidak konsisten \\
\hline Jun-12 & 596 & tetap & 8.14 & naik & tidak konsisten \\
\hline Jul-12 & 596 & tetap & 9.06 & naik & tidak konsisten \\
\hline Agt-12 & 578 & turun & 9.33 & naik & tidak konsisten \\
\hline Sep-12 & 578 & tetap & 9.77 & naik & tidak konsisten \\
\hline Okt-12 & 578 & tetap & 9.85 & naik & tidak konsisten \\
\hline Nov-12 & 584 & turun & 10.02 & naik & tidak konsisten \\
\hline Des-12 & 584 & tetap & 10.02 & tetap & konsisten \\
\hline
\end{tabular}

Sumber: Diolah dan dipublikaskan oleh Bursa Efek Indonesia tahun 2015 
Tabel 4. Hubungan Financial Leverage (DER) dengan Price Earning Ratio (PER) pada PT. Indofood Sukses Makmur

\begin{tabular}{|c|c|c|c|c|c|}
\hline Bulan & DER & Arah & \multicolumn{1}{c}{ PER } & \multicolumn{1}{c}{ Arah } & Keterangan \\
\hline Jan-12 & 0.74 & & 15.04 & & \\
\hline Feb-12 & 0.74 & tetap & 13.3 & naik & tidak konsisten \\
\hline Mar-12 & 0.70 & turun & 13.3 & turun & tidak konsisten \\
\hline Apr-12 & 0.70 & tetap & 13.57 & tetap & tidak konsisten \\
\hline Mei-12 & 0.70 & tetap & 17.14 & turun & tidak konsisten \\
\hline Jun-12 & 0.70 & tetap & 22.78 & naik & tidak konsisten \\
\hline Jul-12 & 0.70 & tetap & 22.61 & naik & tidak konsisten \\
\hline Agt-12 & 0.77 & naik & 23.9 & naik & tidak konsisten \\
\hline Sep-12 & 0.77 & tetap & 24.58 & naik & tidak konsisten \\
\hline Okt-12 & 0.77 & tetap & 25.6 & naik & tidak konsisten \\
\hline Nov-12 & 0.71 & turun & 24.72 & naik & konsisten \\
\hline Des-12 & 0.71 & tetap & 10.91 & tetap & tidak konsisten \\
\hline
\end{tabular}

Sumber: Diolah dan dipublikaskan oleh Bursa Efek Indonesia tahun 2015

Ketidak konsistenan hubungan antara ROE, EPS, dan DER denan PER mendorong peneliti untuk menganalisis bagaimana ROE, EPS dan DER mempengaruhi PER pada PT. Indofood Sukser Makmur periode 2012-2014. Tbk. Oleh karena itu tujuan penelitian ini adalah:

1. Untuk mengetahui pengaruh ROE, EPS, DER terhadap PER secara parsial

2. Untuk mengetahui pengaruh ROE, EPS, DER terhadap PER secara simultan.

Berdasarkan tujuan penelitian di atas, penelitian ini diharapakan mampu memberi kontribusi dalam ilmu manajemen keuangan. Walaupun penelitian sejenis telah dilakukan namun dengan menggunakan sampel data terbaru dengan periode bulanan, diharapkan dapat memberi informasi yang berguna bagi investor dalam mengmbil keputusan investasi dan bagi perusahaan dalam meningkatkan kinerja keuangan.

\section{KAJIAN PUSTAKA PRICE EARNING RATIO (PER)}

Price Earning Ratio adalah perbandingan antara harga pasar saham per lembar dengan laba per lembar saham.
Harga saham di pasar merupakan harga yang berlaku, sedangkan laba bersih merupakan laba bersih per saham proyeksi tahun berjalan. Selain itu Samsul (2011) juga mengemukakan bahwa Price Earning Ratio dipergunakan oleh berbagai pihak atau investor untuk membeli saham. Menurut Agustin (2013) Price Earning Ratio dipengaruhi oleh dua faktor,yaitu laba per saham atau Earning Per Share, dan tingkat resiko investasi atas suatu saham yang disebut ratio. Suatu ratio yang menyatakan berapa kali Earning Per Share itu dapat kembali.

Investor akan membeli suatu saham perusahaan dengan Price Earning Ratio yang kecil, karena Price Earning Ratio yang kecil menggambarkan laba bersih per saham yang cukup tinggi dan harga yang rendah. Faktor-faktor yang dapat mempengaruhi Price Earning Ratio adalah faktor yang sama yang dapat mempengaruhi harga sebuah saham. Investor akan segera merespon dengan cepat setiap perubahan tersebut, yaitu dengan menjual atau membeli saham tersebut yang akhirnya mengubah nilai PER tersebut. Rumus PER adalag sebagai berikut:

$P E R=\frac{\text { Price per Share }}{\text { Earning per Share }}$ 


\section{RETURN ON EQUITY (ROE)}

Return On Equity adalah kemampuan dari modal sendiri untuk menghasilkan laba bagi pemegang saham (Samsul, 201). Return On Equity atau rentabilitas modal merupakan rasio untuk mengukur laba bersih sesudah pajak dengan modal sendiri. Rasio ini menunjukkan efisiensi penggunaan modal sendiri. Semakin tinggi rasio ini, semakin baik. Artinya posisi pemilik perusahaan semakin kuat, demikian pula sebaliknya (Fahmi, 2013). Rumus ROE sebagi berikut:

$R O E=\frac{\text { Net Income }}{\text { Total Equity }}$

\section{EARNING PER SHARE (EPS)}

Earning Per Share (EPS) atau laba per lembar saham adalah tingkat keuntungan bersih untuk tiap lembar sahamnya yang mampu diraih perusahaan pada saat menjalankan operasinya. Laba per lembar saham atau EPS diperoleh dari laba yang tersedia bagi pemegang saham biasa dibagi dengan jumlah ratarata saham biasa yang beredar. Menurut Fahmi (2013), mendefinisikan earning per share sebagai berikut bentuk pemberian keuntungan yang diberikan kepada para pemegang saham dari setiap lembar saham yang dimiliki. Rumus EPS sebagai berikut:

$E P S=\frac{\text { Net Income-Prefferd Devidens }}{\text { Average Number of Commen Share Outstanding }}$

\section{DEBT TO EQUITY RATIO (DER)}

Debt to Equity Ratio (DER) atau Financial Leverage adalah penggunaan hutang sebagai sumber pembiayaan perusahaan. Leverage juga merupakan perbandingan antara jumlah total hutang dengan total aktiva yang menggambarkan sampai berapa besar perusahaan menggunakan hutang dalam struktur modal. Samsul (2011) yang menyatakan bahwa variabel Debt to Equity Ratio (DER) berpengaruh terhadap Price Earning Ratio. Menurut Fahmi (2013), Debt to Equity Ratio (DER) berguna untuk mengetahui jumlah dana yang disediakan peminjam (kreditor) dengan pemilik perusahaan. Rasio DER akan memberikan arti yang berbeda bagi kreditor dan perusahaan. Bagi Bank (kreditor), semakin besar rasio ini akan semakin tidak menguntungkan, karena semakin besar resiko yang ditanggung atas kegagalan yang mungkin terjadi di perusahaan (Fahmi, 2013). Rumus $D E R$ sebagai berikut:

$D E R=\frac{\text { Total Debt }}{\text { Total Equity }}$

\section{Pengaruh variabel Return On Equity terhadap Price Earning Ratio}

Pengaruh variabel Return On Equity dengan Price Earning Ratio adalah positif (Hayati 2010). Hasil studi Purwaningrum (2011) menunjukkan Return On Equity signifikan terhadap Price Earning Ratio namun berhubungan negatif. Hasil studi Ramadhani (2012) juga menunjukan bahwa variabel Return On Equity mempunyai pengaruh negatif terhadap Price Earning Ratio.

Pengaruh variabel Earning Per Share terhadap Price Earning Ratio

Menurut Sitepu dan Efendi (2014) pengaruh variabel Earning Per Share dengan Price Earning Ratio adalah signifikan dan negatif. Variabel Earning Per Share juga memiliki hubungan yang positif dan signifikan menurut Rahma, Djumahir dan Djazuli (2014). Studi Agustin (2013) menunjukkan bahwa Price to Book Value, Earning Per Share dan Return On Asset mempunyai pengaruh yang signifikan terhadap Price Earning Ratio.

\section{Pengaruh variabel Debt to Equity Ratio terhadap Price Earning Ratio}

Hasil studi Sunaryo (2011) menujukan Financial Leverage berpengaruh terhadap Price Earning Ratio. Studi Taufiq, Rahayu, Azizah (2015) mnunjukan bahwa variabel Return On Equity, Debt To Equity Ratio dan Dividend Payout Ratio mempunyai pengaruh yang signifikan terhadap Price Earning Ratio. 


\section{Kerangka Berpikir}

Berdasarkan kajian teori dan hasil penelitian terdahulu, dapat dirumuskan model penelitian sebagai berikut:

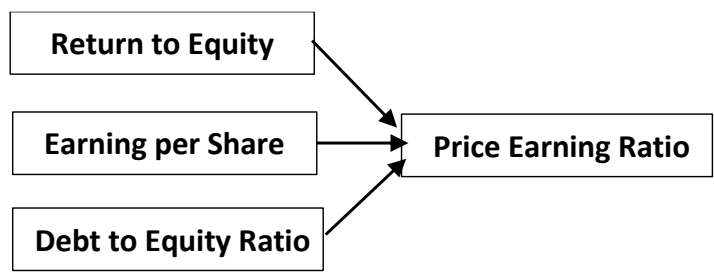

Gambar 1. Kerangka pemikiran.

\section{Hipotesis Penelitian}

Berdasarkan kerangka berpikir di atas maka hipotesis penelitian ini adalah sebagai berikut:

H1 Ada pengaruh yang signifikan pada variabel Return on Equity, Earning per Share, dan Debt to Equity Ratio secara parsial terhadap Price Earning Ratio.

H2 Ada pengaruh yang signifikan pada variabel Return on Equity, Earning per Share, dan Debt to Equity Ratio secara simulatan terhadap Price Earning Ratio

\section{METODE PENELITIAN}

Penelitian ini menggunakan metode penelitian kuantitatif Data yang digunakan peneliti dalam penelitian ini adalah data sekunder, yaitu data laporan keuangan bulanan PT. Indofood Sukses Makmur Tbk. Periode laporan keunagan yang digunakan adalah sejak bulan Januari 2012 sampai dengan bulan Desember tahun 2014, dengan total data adalah 36 bulan. Metode analisis yang digunakan untuk menghubungkan tiga variabel bebas yang terdiri dari Return On Equity (ROE), Earning Per Share (EPS), dan Financial Leverage (DER) yang mempengaruhi variabel terikat Price Earning Ratio (PER) maka digunakan analisis regresi berganda. Adapun persamaan linier dari model ini tersaji pada persamaan (5). Uji hipotesis yang digunakan adalah uji hipotesis parsial dengan uji-t dan uji hipotesis secara simultan dengan uji-F.
$\mathrm{PER}=\mathrm{C}+\beta_{1} \mathrm{ROE}+\beta_{2} \mathrm{EPS}+\beta_{3} \mathrm{DER}$

\section{HASIL DAN PEMBAHASAN}

Dari pengolahan data variabel penelitian dengan teknik analisis regresi berganda diperoleh hasil sebagai berikut:

Tabel 5. Hasil Regresi Model PER

\begin{tabular}{|c|c|cc|c} 
Variabel & $\begin{array}{c}\text { Coeffi } \\
\text { cient }\end{array}$ & $\begin{array}{c}\mathrm{t} \text { Stat } \\
\mathrm{t} \text { tabel } \\
(5 \%)\end{array}$ & Keterangan \\
\hline ROE & $-0,897$ & $-2,237$ & & Signifikan \\
\hline EPS & 0,077 & 1,771 & 2,0369 & $\begin{array}{c}\text { Tidak } \\
\text { Signifikan }\end{array}$ \\
\hline DER & 7,055 & 3,828 & & Signifikan \\
\hline
\end{tabular}

Sumber: Hasil olah SPSS, Tabel-t

Pengaruh Varibel Return on Equity, Earning per Share, dan Debt to Equity Ratio Secara Parsial terhadap Price Earning Ratio

\section{Pengaruh Return on Equity terhadap Price Earning Ratio}

Variabel Return on Equity signifikan karena pada t-stat menunjukkan angka -2,237 yang lebih kecil dari t tabel 2,036. Artinya Return on Equity mampu memprediksi tingkat keuntungan dari investasi pemilik modal pada saham PT. Indofood Sukses Makmur. Bagi investor nilai ROE memberikan informasi tentang seberapa besar tingkat pengembalian modal dari perusahaan yang berasal dari kinerja perusahaan menghasilkan laba. Nilai koefisien Return on Equity -0,897, menunjukan bahwa Return on Equity memiliki dampak negatif terhadap Price Earning Ratio. Artinya setiap kenaikan 1\% Return on Equity dengan asumsi variabel tetap akan menurunkan Price Earning Ratio sebesar $0,897 \%$. Semakin besar nilai ROE PT.indofood Sukses Makmur semakin kecil nilai PER. Secara teori semakin besar nilai ROE semakin baik perusahaan tsb. Namun hal ini berbeda dengan pa yang terjadi pada PT. Indofood, diduga karena selama periode penelitian pergerakan ROE yang tidak konsisten dengan pergerakan PER (Tabel 2). 


\section{Pengaruh Earning per Share terhadap Price Earning Ratio}

Hasil uji-t variabel Earning per Share pada PT. Indofood Sukses berpengaruh tidak signifikan terhadap Price Earning Ratio pada $\alpha=5 \%$. Variabel Earning Per Share tidak signifikan karena pada $t$ stat menunjukkan angka 1,771 yang artinya lebih kecil dari t-tabel 2,036. Nilai koefisien Earning per Share 0,007, menunjukan bahwa Earning Per Share memiliki dampak positif terhadap Price Earning Ratio. Artinya setiap kenaikan $1 \%$ Earning per Share dengan asumsi variabel tetap akan meningkatkan Price Earning Ratio sebesar 0,007\%. Keputusan investor dalam berinvestasi pada PT. Indofood Sukses Makmur tidak dipengaruhi oleh EPS.

\section{Pengaruh Deabt to Equity Ratio terhadap Price Earning Ratio}

Hasil uji-t variabel Debt to Equity Ratio (DER) pada PT. Indofood Sukses Makmur berpengaruh signifikan terhadap Price Earning Ratio pada $\alpha=5 \%$. Variabel Debt to Equity Ratio (DER) signifikan karena pada t-stat 3,828 yang artinya lebih besar dari t tabel 2,036. Nilai koefisien Debt to Equity Ratio (DER) 7,055, menunjukan Debt to Equity Ratio (DER) memiliki dampak positif terhadap Price Earning Ratio. Artinya setiap kenaikan $1 \%$ Debt to Equity Ratio (DER) dengan asumsi variabel tetap akan menaikkan Price Earning Ratio sebesar 7,055\%. Nilai Debt to Equity Ratio (DER) mencerminkan kemampuan perusahaan untuk memenuhi kewajibannya yang ditunjukkan berapa bagian modal sendiri yang digunakan untuk membayar keseluruhan hutang. Nilai DER yang positif menujukan bahwa pendapatan yang diterima PT. Indofood Sukses Makmur dari penggunaan lebih besar dari beban tetap yang harus dikeluarkan atas penggunaan dana tersebut.

Berdasrkan Tabel 5. Variabel DER memiliki nilai koefisien paling besar dibandingkan variabel ROE dan EPS.
Dapat dikatakan bahwa variabel DER memiliki pengaruh dan dampak yang paling dominan terhadap PER. Hal ini menunjukan bahwa variabel ini menjadi indikator paling penting bagi investor dalam mengambil keputusan berinvestasi pada PT. Indofood Sukses Makmur.

Pengaruh Varibel Return on Equity, Earning per Share, dan Debt to Equity Ratio Secara Simultan terhadap Price Earning Ratio

Berdasarkan hasil uji simultan dnegan uji-f pada Tabel 6 Variabel Return on Equity, Earning per Share dan Debt to Equity Ratio pada PT.Indofood Sukses Makmur secara simultan berpengaruh terhadap Price Earning Ratio dengan nilai probabilitas 0,000 yang lebih kecil dari 5\%. Perbandingan ini menunjukkan hasil yang signifikan.

Tabel 6. Hasil Uji Simultan

\begin{tabular}{lll}
\hline F & Sig & Keterangan \\
\hline $\mathbf{1 6 9 , 5 0}$ & 0,000 & Signifikan $(<0,05)$ \\
\hline
\end{tabular}

Sumber: Hasil olah SPSS

\section{SIMPULAN}

Dari hasil penelitian ini dapat disimpulkan bahwa:

1. Variabel Return on Equity dan variabel Debt to Equity Ratio secara parsial berpengaruh signifikan terhadap Price Earning Ratio. Namun variabel Earning per Share tidak berpengaruh signifikan secara parsial terhadap Price Earning Ratio. Variabel yang memiliki dampak terbesar dan memiliki pengaruh dominan terhadap Price Earning Ratio adalah Debt to Equity Ratio.

2. Variabel Return on Equity, Earning per Share, dan Debt to Equity Ratio secara simultan berpengaruh terhadap Price Earning Ratio.

\section{DAFTAR PUSTAKA}

1. Agustin, R. F., Analisis Pengaruh $P B V$, EPS, dan ROA terhadap PER 
pada perusahaan pertambangan di Bursa Efek Indonesia periode 20092012, Sistem Informasi Jurnal Ilmiah USM, 70-80, 2013.

2. Bursa Efek Indonesia, Laporan Keuangan Tahunan. Retrieved from http://www.idx.co.id

3. Fahmi, I., Analisis Laporan Keuangan. Bandung: Alfabeta, 2013.

4. Hayati, N., Faktor-Faktor Yang Mempengaruhi Price Earning Ratio Sebagai Salah Satu Kriteria Keputusan Investasi Saham Perusahaan Real Estate dan Property di Bursa Efek Indonesia, Jurnal Manajemen dan Akuntansi Vol 11. No 1, 53-62, 2010.

5. Indofood, Indofood, Retrieved December 20, 2016: http://www.indofood.com

6. Purwaningrum, E., Factors Effecting Price earning ratio of Company's Share in the Manufacture Sector. Jurnal Ekonomi dan Bisnis Vol 10 no 1, 90-110, 2011.

7. Rahma, E. Y., Djumahir, \& Djazuli, A., Analisis Variabel Fundamental yang berpengaruh terhadap Price Earning Ratio sebagai Dasar Penilaian Saham pada Perusahaan Automotive and Allied yang terdaftar di Bursa Efek Indonesia . Jurnal Aplikasi Manajemen Volume 12 No 3, 28-38, 2014.

8. Ramadhani, G., Analisis FaktorFaktor Yang Mempengaruhi Price Earning Ratio Pada Perusahaan Manufaktur Yang Terdaftar di Bursa Efek Indonesia 2007-2011, 80-90, 2012.

9. Samsul, M., Pasar Modal dan Manajemen Portofolio. PT. Gelora Aksara Pratama, 2011.

10. Sitepu, D., Effendi, J., Analisis FaktorFaktor Yang Mempengaruhi Price Earning Ratio Perusahaan Perusahaan Consumer Goods di Bursa Efek Indonesia. Jurnal Wira Ekonomi Mikroskill Volume 04, 82-98, 2014.

11. Sunaryo, Pengaruh Current Ratio, Debt to Equity, dan Dividend Payout Ratio, terhadap Price Earning Ratio pada kelompok Perusahaan Manufaktur yang terdaftar di Bursa Efek Indonesia. Jurnal Akuntansi, Fakultas Ekonomi dan Bisnis, Universitas Bina Nusantara. Volume 2 No.2, 866-873, 2011.

12. Taufiq, R., Rahayu, S. M., \& Azizah, D. F., Analisis Pengaruh Return On Equity, Debt To Equity Ratio dan Dividend Payout Ratio terhadap Price Earning Ratio (Studi pada SahamSaham Perbankan yang terdaftar di Indeks LQ 45 BEI priode 2007-2011). Jurnal Administrasi Bisnis Vol. 21, 99120, 2015. 